\title{
Front Matter: Volume 9572
}

, "Front Matter: Volume 9572," Proc. SPIE 9572, Nonimaging Optics: Efficient Design for Illumination and Solar Concentration XII, 957201 (10 September 2015); doi: 10.1117/12.2208516

EDent: SPIE Optical Engineering + Applications, 2015, San Diego, California, SPIE. United States 


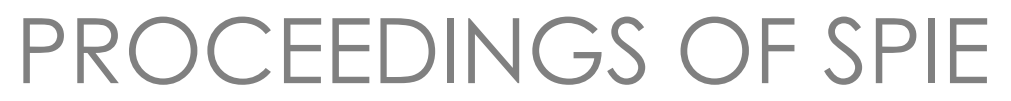

\title{
Nonimaging Optics: Efficient Design for Illumination and Solar Concentration XII
}

\author{
Roland Winston \\ Jeffrey M. Gordon \\ Editors
}

9-10 August 2015

San Diego, California, United States

Sponsored and Published by

SPIE 
The papers included in this volume were part of the technical conference cited on the cover and title page. Papers were selected and subject to review by the editors and conference program committee. Some conference presentations may not be available for publication. The papers published in these proceedings reflect the work and thoughts of the authors and are published herein as submitted. The publisher is not responsible for the validity of the information or for any outcomes resulting from reliance thereon.

Please use the following format to cite material from this book:

Author(s), "Title of Paper," in Nonimaging Optics: Efficient Design for Illumination and Solar Concentration XII, edited by Roland Winston, Jeffrey M. Gordon, Proceedings of SPIE Vol. 9572 (SPIE, Bellingham, WA, 2015) Article CID Number.

ISSN: 0277-786X

ISBN: 9781628417388

\section{Published by}

\section{SPIE}

P.O. Box 10, Bellingham, Washington 98227-0010 USA

Telephone +1 3606763290 (Pacific Time) · Fax +1 3606471445

SPIE.org

Copyright (@ 2015, Society of Photo-Optical Instrumentation Engineers.

Copying of material in this book for internal or personal use, or for the internal or personal use of specific clients, beyond the fair use provisions granted by the U.S. Copyright Law is authorized by SPIE subject to payment of copying fees. The Transactional Reporting Service base fee for this volume is $\$ 18.00$ per article (or portion thereof), which should be paid directly to the Copyright Clearance Center (CCC), 222 Rosewood Drive, Danvers, MA 01923. Payment may also be made electronically through CCC Online at copyright.com. Other copying for republication, resale, advertising or promotion, or any form of systematic or multiple reproduction of any material in this book is prohibited except with permission in writing from the publisher. The CCC fee code is 0277-786X/15/\$18.00.

Printed in the United States of America.

Publication of record for individual papers is online in the SPIE Digital Library.

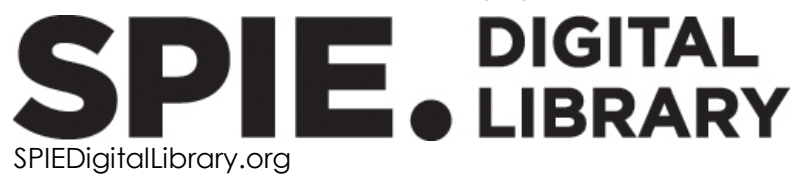

Paper Numbering: Proceedings of SPIE follow an e-First publication model, with papers published first online and then in print. Papers are published as they are submitted and meet publication criteria. A unique citation identifier (CID) number is assigned to each article at the time of the first publication. Utilization of CIDs allows articles to be fully citable as soon as they are published online, and connects the same identifier to all online, print, and electronic versions of the publication. SPIE uses a six-digit CID article numbering system in which:

- The first four digits correspond to the SPIE volume number.

- The last two digits indicate publication order within the volume using a Base 36 numbering system employing both numerals and letters. These two-number sets start with 00, 01, 02, 03, 04, $05,06,07,08,09,0 A, 0 B \ldots$. OZ, followed by 10-1Z, 20-2Z, etc.

The CID Number appears on each page of the manuscript. The complete citation is used on the first page, and an abbreviated version on subsequent pages. 


\title{
Contents
}

\author{
$\checkmark \quad$ Authors \\ vii Conference Committee \\ ix Introduction
}

\section{SESSION 1 NOVEL DESIGNS AND CORE CONCEPTS}

957202 String method of nonimaging optics from a radiation theory perspective [9572-1]

957203 Asymmetric design for Compound Elliptical Concentrators (CEC) and its geometric flux implications [9572-2]

957204 All fiber actively mode-locked fiber laser emitting cylindrical vector beam [9572-3]

957205 Improved and customized secondary optics for photo-voltaic concentrators [9572-4]

\section{SESSION 2 SOLAR CONCENTRATORS AND SYSTEMS I}

957206 Dielectric totally internally reflecting concentrator structure for vertical bifacial photovoltaic receivers [9572-5]

\section{SESSION 3 SOLAR CONCENTRATORS AND SYSTEMS II}

957208 Hybrid solar collector using nonimaging optics and photovoltaic components (Invited Paper) [9572-7]

$95720 \mathrm{~A}$ Self-tracking concentrator based on switchable transparency and rejected-ray recycling [9572-9]

9572 OB Design of a solar collector system formed by a Fresnel lens and a CEC coupled to plastic fibers [9572-10]

\section{SESSION 4 SOLAR CONCENTRATORS AND SYSTEMS III}

9572 OD Fundamentally new classes of aplanatic lenses (Invited Paper) [9572-12]

\section{SESSION 5 ILLUMINATION AND IRRADIATION OPTICS}

9572 OG Efficient color mixing through étendue conservation using freeform optics [9572-15] 
$9572 \mathrm{OH} \quad$ Illumination system design with multi-step optimization [9572-16]

9572 Ol Light extraction method for mixing rods based in grooves with elliptical shape [9572-17]

\section{SESSION 6 FREEFORM OPTICS}

9572 OK Design of diffractive optical surfaces within the SMS design method (Invited Paper) [9572-19]

9572 OL Exact wavefront surface refracted by a smooth arbitrary surface considering a plane wavefront incident [9572-20]

9572 OM Freeform aplanatic concentrators [9572-21]

$95720 \mathrm{~N} \quad$ Non-uniformly sampled grids in double pole coordinate system for freeform reflector construction [9572-22]

957200 Diffraction effects in freeform optics [9572-23]

POSTER SESSION

9572 OP Development of daylighting systems with non-imaging concentrator [9572-24] 


\section{Authors}

Numbers in the index correspond to the last two digits of the six-digit citation identifier (CID) article numbering system used in Proceedings of SPIE. The first four digits reflect the volume number. Base 36 numbering is employed for the last two digits and indicates the order of articles within the volume. Numbers start with 00, 01, 02, 03, 04, 05, 06, 07, 08, 09, 0A, 0B...0Z, followed by 10-1Z, 20-2Z, etc.

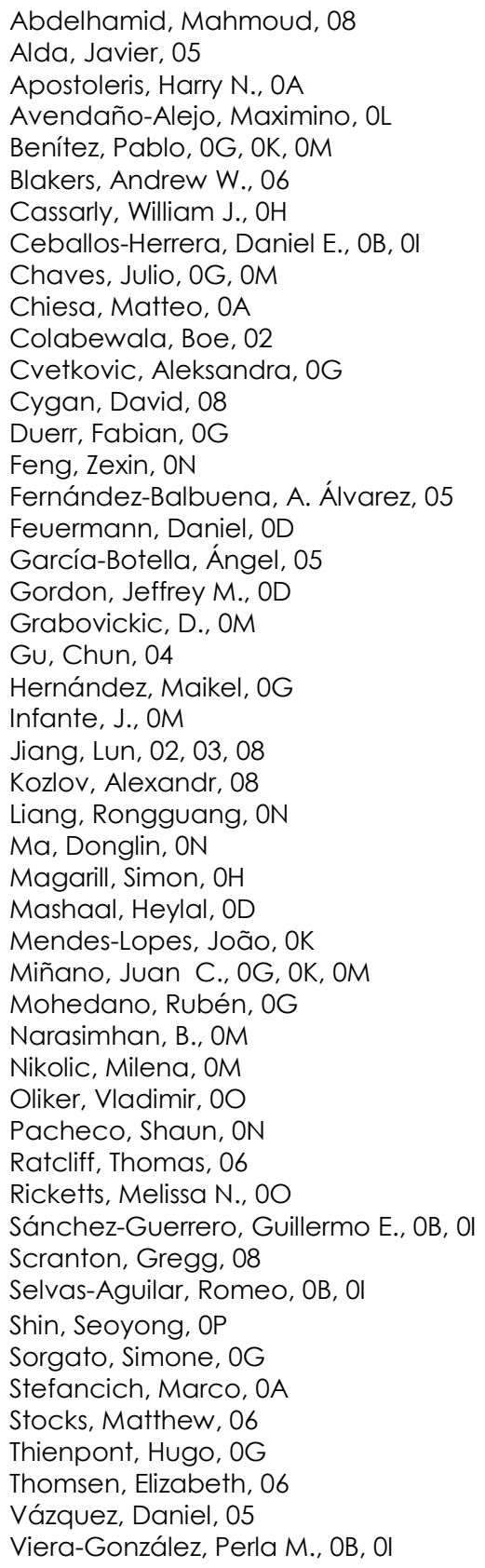

Vu, Ngoc Hai, OP

Wang, Anting, 04

Widyolar, Bennett K., 08

Winston, Roland, 02, 03, 08, 00

$\mathrm{Xu}$, Lixin, 04

Yablonovitch, Eli, 08

Zhan, Qiwen, 04

Zhou, Yong, 04 
Proc. of SPIE Vol. $9572957201-6$

Downloaded From: https://www.spiedigitallibrary.org/conference-proceedings-of-spie on 26 Apr 2023 Terms of Use: https://www.spiedigitallibrary.org/terms-of-use 


\section{Conference Committee}

Program Track Chair

Ian T. Ferguson, The University of North Carolina at Charlotte (United States)

Conference Chairs

Roland Winston, University of California, Merced (United States)

Jeffrey M. Gordon, Ben-Gurion University of the Negev (Israel)

Conference Program Committee

Pablo Benítez, CeDInt-UPM (Spain) and Light Prescriptions Innovators LLC (United States)

William J. Cassarly, Synopsys, Inc. (United States)

Daniel Feuermann, Ben-Gurion University of the Negev (Israel)

Juan Carlos Miñano, Universidad Politécnica de Madrid (Spain) and Light Prescriptions Innovators LLC (United States)

Narkis E. Shatz, SureFire, LLC (United States)

Session Chairs

1 Novel Designs and Core Concepts

Narkis E. Shatz, SureFire, LLC (United States)

2 Solar Concentrators and Systems I

Jeffrey M. Gordon, Ben-Gurion University of the Negev (Israel)

3 Solar Concentrators and Systems II

Daniel Feuermann, Ben-Gurion University of the Negev (Israel)

4 Solar Concentrators and Systems III

Roland Winston, University of California, Merced (United States)

5 Illumination and Irradiation Optics

Gary Rosengarten, RMIT University (Australia)

6 Freeform Optics

William Cassarly, Synopsys, Inc. (United States) 
Proc. of SPIE Vol. $9572957201-8$

Downloaded From: https://www.spiedigitallibrary.org/conference-proceedings-of-spie on 26 Apr 2023 Terms of Use: https://www.spiedigitallibrary.org/terms-of-use 


\section{Introduction}

Welcome to Nonimaging Optics: Efficient Design for Illumination and Solar Concentration XII.

While the first SPIE Nonimaging Optics conference dates back to 1991 (its 25th anniversary is approaching), I am both gratified and astonished at the novelty and creativity on display at every conference. This year's is no exception. Here is my incomplete list of nascent directions: the connections between nonimaging optics and radiative transfer are being revealed by connecting flow-lines to Hottel strings. Aplanatism, that common meeting ground between imaging and nonimaging methods, is being systematically developed. Freeform optics is so advanced that diffraction effects are being evaluated. Edge-ray and SMS methods, which are the staples of nonimaging optical design, are being further developed with some beautiful examples in both concentrating and illumination systems. Recent work reported on energy systems shows that nonimaging optics is making significant inroads. The advantages over classical imaging designs are being recognized by mainstream agencies, such as ARPA-E (Advanced Research Projects AgencyEnergy).

Finally, it is a pleasure to recognize this year's significant participation of Australian scientists and engineers, specifically a collaboration called MUSIC (Micro Urban Solar Integrated Concentrators) comprised of RMIT University, the Australian National University, the University of New South Wales, and Rheem Australia Pty, Ltd. from Australia, as well as Arizona State University, the University of Tulsa, and the University of California, Merced from the United States.

Roland Winston Jeffrey M. Gordon 
Proc. of SPIE Vol. $9572957201-10$

Downloaded From: https://www.spiedigitallibrary.org/conference-proceedings-of-spie on 26 Apr 2023 Terms of Use: https://www.spiedigitallibrary.org/terms-of-use 